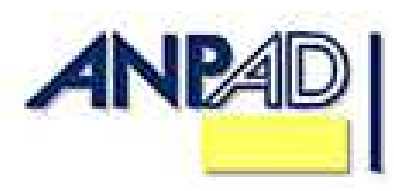

Available online at http://www.anpad.org.br/bar

BAR, Rio de Janeiro, v. 9, Special Issue, art. 5, pp. 78-94, May 2012

\title{
Is ISO 14001 Certification Effective? An Experimental Analysis of Firm Profitability
}

\author{
Renato Tognere Ferron * \\ E-mail address: renato@bandes.com.br \\ Fucape Business School \\ Vitória, ES, Brazil. \\ Bruno Funchal \\ E-mail address: bfunchal@fucape.br \\ Fucape Business School \\ Vitória, ES, Brazil. \\ Valcemiro Nossa \\ E-mail address: valcemiro@fucape.br \\ Fucape Business School \\ Vitória, ES, Brazil. \\ Aridelmo J. C. Teixeira \\ E-mail address: aridelmo@fucape.br \\ Fucape Business School \\ Vitória, ES, Brazil.
}

Copyright (C) 2012 Brazilian Administration Review. All rights reserved, including rights for translation. Parts of this work may be quoted without prior knowledge on the condition that the source is identified. 


\begin{abstract}
This paper examines the effect environmental management certification (ISO 14001) has on publicly traded Brazilian companies profitability. Signaling theory predicts that the certification serves to signal to society good environmental behavior; allowing people to screen the different types of firms, improving the financialeconomic performance of those firms that engage in this behavior. We performed difference-in-difference fixed effect design comparing the financial performance of companies with and without certification of their environmental management systems, using data on 552 companies over the period from 1996 to 2008. The results indicate that firms with an environmental management system certified according to the NBR ISO 14001:2004 standard tended to be more profitable, on average, than firms without certification.
\end{abstract}

Key words: certification; profitability; NBR ISO 14001:2004. 


\section{Introduction}

The goal of this paper is to verify if environmental management system (EMS) certification impacts the profitability of publicly traded Brazilian firms. In general, companies are facing increasing pressure from stakeholders - among them governments, local communities and non-governmental organizations (NGOs) - regarding respect for the environment (see Schaltegger \& Burritt, 2000). But, if shareholders primarily care about profits, should environment policies really matter?

Initially, there is a cost to obtain environmental management certification. But what can we say about returns on this investment? According to Sanches (1996), besides concern about the environmental impacts of their activities, firms are also influenced by commercial questions, mainly those related to the demands of international consumers. Also, the author argues that firms are facing increasing contractual obligations to adopt a policy of environmental preservation and reclamation, by means of an environmental management system (written as EMS henceforth). For Bansal and Roth (2000), there are three main factors that influence firms to be concerned about the environment and thus invest in sustainable development: pressures from stakeholders, commercial opportunities and legal obligations.

Furthermore, according to Harrington and Knight (2001), an EMS, when strategically implemented, can bring various economic benefits, reflected both in market gains and cost reductions. It can also facilitate access to funding sources, especially so-called sustainable financing, and to international markets, particularly the European and American markets. In this respect, Rao and Holt (2005) indicated there are many benefits of being EMS certified, such as increased market share, advantages for stakeholders, reduction of risks, reduction of costs and increased productivity, among others. Henri and Giasson (2006) believe that a firm can gain a competitive advantage through responsible interaction with stakeholders on environmental questions, and by conforming to legal and regulatory requirements. This competitive advantage is reflected in positive financial results. Tinoco and Kraemer (2004) point to the existence of pressure related to various environmental problems, among them the reduction of natural resources (particularly fresh water), extinction of plant and animal species, and global warming provoked by burning fossil fuels.

By means of EMS certification according to NBR ISO 14001:2004, firms signal to the market that they are producing their products and rendering their services with respect for the environment. This signaling attempts to mitigate the problem of adverse selection, in which consumers wind up acquiring products and services without knowing to what extent companies respect environmental laws and standards.

According to Akerlof (1970), the problem of adverse selection is potentially present in all fields of activity, as long as there is a relationship between two parties in which one has more information than the other. This occurs, for example, in the insurance market, financial market (especially in underdeveloped countries) and labor market. Therefore, given the firm's potential gains and losses from the certification, we were interested to discover if NBR-ISO 14001 increases profitability.

From a panel data set with Brazilian firms as cross-section units from 1996 to 2009, we use an experiment design called difference-in-difference with fixed effects. This design compares the outcomes of certified firms, called the treatment group, with outcomes of non-certified firms, called the control group. The control group is expect to emulate the treatment group behavior if the certification had not been implemented, acting as a replacement for the ideal but unobserved counterfactual we needed.

Our results show that on average, using the two-side fixed effects specification, firms that implemented the EMS certification get an EBITDA and a Net Income (our measures of profitability) $11 \%$ and $24.6 \%$ higher, respectively, than firms without EMS certification. This means that firms that implement EMS certification tend to increase their economic-financial results. 
This study is justified by the discussion about management practices that try to reduce or eliminate environmental impacts caused by business activity, and whether these actions can bring competitive advantages to firms.

The contribution of this work is associated with the evidence it brings to bear on the question of whether or not implementation of an environmental management system certified according to NBR ISO 14001:2004 enhances firm profitability. Our main result suggests that EMS certification can be used by managers as a profit-oriented policy and not only as a way to fulfill social demands.

This paper is organized into six sections, including this introduction, which presents the theme and its context, and touches on the relevance of environmental concern. The second section presents a brief theoretical review, highlighting the concepts of agency theory (Jensen \& Mecking 1976), information asymmetry, adverse selection and signaling (Spence, 1973), as well as the main aspects of environmental laws, previous studies on the subject and the overall concept of NBR ISO 14001:2004. Then, the third section examines in more detail the various aspects of EMS certification according to ISO 14000. The fourth section describes the approaches, methods and tests applied in the present study. The fifth section analyzes and interprets the sample data and presents the results of the tests performed. Finally, the sixth section presents the conclusions, indicates some limitations and suggests future avenues for research.

\section{Theoretical Framework}

\section{Asymmetric information, adverse selection and signaling}

Jensen and Mecking (1976) developed agency theory, based on the existence of a market in which economic parties - companies, consumers, governments, etc. - establish bilateral contracts to develop an economic activity. They pointed out that in a bilateral relationship, a conflict can arise when the agent, intent on maximizing personal utilities, puts these above the interests of the principal, whose well-being the agent is supposed to be maximizing. According to them, the central element of this conflict of interests between the principal and agent is asymmetric information; i.e., when one of the parties has information the other does not possess. In this case, the agent has privileged information not available to the principal.

Information is an essential element of economic relations, especially regarding the process of competition among firms, and information asymmetry plays an important role in the relationship between companies and their customers, the consumers of their products and services. For Akerlof (1970), adverse selection exists because of the inefficiency of selection when purchasing a product or service, since companies can offer goods and services without proper concern for the environmental impacts of their activities.

The absence of information in this respect means consumers wind up acquiring products and services without knowing which companies are more respectful of environmental protection laws and standards.

Because of asymmetric information, as mentioned earlier, the economic relations between parties are inefficient. This asymmetry can lead, for example, to the purchase of products and services by consumers that degrade the environment in some form. Spence (1973) demonstrated how parties in a market can use signaling to react to the effects of adverse selection, with signaling defined as observable actions by firms to convince other parties of the value and quality of the products and services offered to the market.

For Williamson (1985), based on institutional theory, there are two basic mechanisms to reduce information asymmetry with the aim of diminishing adverse selection: signaling and screening. 
Signaling involves the supply of information by the firm, based on the premise that the party that is receiving the information trusts the other party's signaling. In turn, screening occurs when the information asymmetry is overcome at the initiative of the uninformed party in search of information.

This is the case of consumers who seek information by establishing contact only with parties that have the information within the desired parameters. Various companies, both abroad and in Brazil, have been using this theory to try to reduce information asymmetry and thus the adverse selection of their products and services, by setting up an environmental management system (EMS).

\section{Environmental laws and regulations}

Regardless of establishing an EMS and then obtaining certification through the NBR ISO 14001:2004 standard, all firms must comply with the environmental laws and regulations covering their activity. According to Tinoco and Kraemer (2004), firms that fail to meet all the legal provisions applicable to their activity can suffer both administrative and judicial sanctions, such as having to pay fines and losses and damages to plaintiffs. In Brazil, all three levels of government have authority to legislate concerning the environment.

Therefore, firms must be aware of and follow the legal framework at the federal, state and municipal levels. To obtain NBR ISO 14001:2004 certification, firms must be compliant with all legal requirements. This reduces the probability of being fined by regulators and being sued by individual consumers or facing class actions.

\section{Previous studies}

Klassen and Mclaughlin (1996) identified positive effects on the market value of firms after they announced receiving awards or positive environmental actions, and negative returns because of environmental accidents. Russo and Fouts (1997), using statistical methods (multiple regression), with return on assets (ROA) as the dependent variable, concluded that a high level of environmental performance is associated with an increase in return.

Analyzing 112 North American companies, Konar and Cohen (1997) showed a positive influence of environmental investments, and consequent reduction of the emission of pollutants, on the market value of such companies.

Based on the evaluation of companies in the sectors of cellulose and paper, automotive and chemical, Gupta and Goldar (2003) concluded that information related to environmental performance can influence share price as a result of shareholders' expectations

Using a sample of American firms analyzed between 1996 and 2002, Jiangning (2006) investigated the financial performance in light of the environmental information contained in annual reports, separating firms that did and did not have environmental certification.

They analyzed this performance through the metrics return on assets (ROA), return on revenue (ROR) and operating revenue (OPR). According to their statistical tests, it was not possible to find significant differences between the two groups of firms for the variables employed.

In the same direction as the above studies, the survey by Ann, Zailani and Wahid (2006), by means of questionnaires answered by executives of Malaysian firms, examined the impact of environmental certification (ISO 14001) on their financial performance. The results indicated that while ISO 14001 certification is perceived positively in the environmental sphere, this does not carry over to the bottom line, since it does not help reduce the time or cost of production. Besides this, the firms that answered the questionnaire tended to believe that the benefits of certification were not worth the necessary investment. 
In Brazil very few studies have been published on this matter, especially ones trying to relate certification of an environmental management system as specified in NBR ISO 14001:2004 with financial performance. Alberton (2003) performed an event study using a sample of Brazilian firms with NBR ISO 14001 certification (1996 version), seeking to identify a positive impact on their financial performance.

Even using more than one statistical model, it was not possible to identify abnormal returns due to certification, but the tests also did not reveal any reduction in profitability associated with implementation of an EMS and obtaining certification.

Another study of the Brazilian market was performed by Rodrigues and Ferreira (2006), who analyzed the profitability of Brazilian steel makers that obtained NBR ISO 14001:2004 certification.

According to the authors, the results in general indicated a positive relation between environmental management and the financial indicators of these firms. Finally, Castro (2006) analyzed the influence of an environmental management system certified according to NBR ISO 14001:2004 on the market value of Brazilian firms and did not find any increase in the market value of these companies. As can be seen, there is no consensus on the importance of obtaining certification according to the NBR ISO 14001:2004 standard and the possible financial impacts, particularly firm profitability.

Our results add to the literature in two ways: first, we use a quasi-experimental approach called differences-in-differences that helps to reduce the bias in the estimation due to endogeneity problems; second, we analyze profit measures, which are the most important measures to shareholders.

\section{The ISO 14000 Series}

Founded in 1947, with headquarters in Geneva, Switzerland, the International Organization for Standardization (ISO) is a non-governmental organization whose standards are adopted in over 120 countries. According to Nossa (2002), the most accepted EMS certification in Brazil is that of the ISO 14001 standard, created in 1996 by the International Organization for Standardization. The local entity responsible for this certification is the Brazilian Association of Technical Standards (Associação Brasileira de Normas Técnicas [ABNT]), and the most recent Brazilian version is called NBR ISO 14001:2004.

The process of certifying the environmental management systems of Brazilian companies by means of NBR ISO 14001 began in 1996. After nearly a decade, the NBR ISO 14001 standard was revised and updated, to accompany the evolution of the concepts of environmental protection. This effort was completed on November 11, 2004, and the revised standard took effect on January 1, 2005.

One of the main purposes of certification based on NBR ISO 14001:2004 is ongoing improvement of environmental performance by means of environmental management, usually through formal establishment of an EMS. All firms whose environmental management systems were certified by NBR ISO 14001:1996 were analyzed again for certification based on the NBR ISO 14001:2004 version. According to Züst (1997), the ISO 14001 standard concentrates on improving firms' performance in the areas of operations, products and services, with the main focus on environmental impacts.

The NBR ISO 14001 standard describes the basic elements of effective environmental management, including the creation of an environmental policy, establishment of objectives, implementation of a program to attain these goals, monitoring and measurement of the program's efficacy, correction of problems, and analysis and revision of the system. 
Of the series of standards referring to environmental management systems, NBR ISO 14001:2004 is the one with the objective of certification. The other standards in the series only help in the process of implementing the EMS, and consequently of its certification.

In the modified version, the series has the following structure (Table 1):

Table 1

\section{ISO 14001 Series}

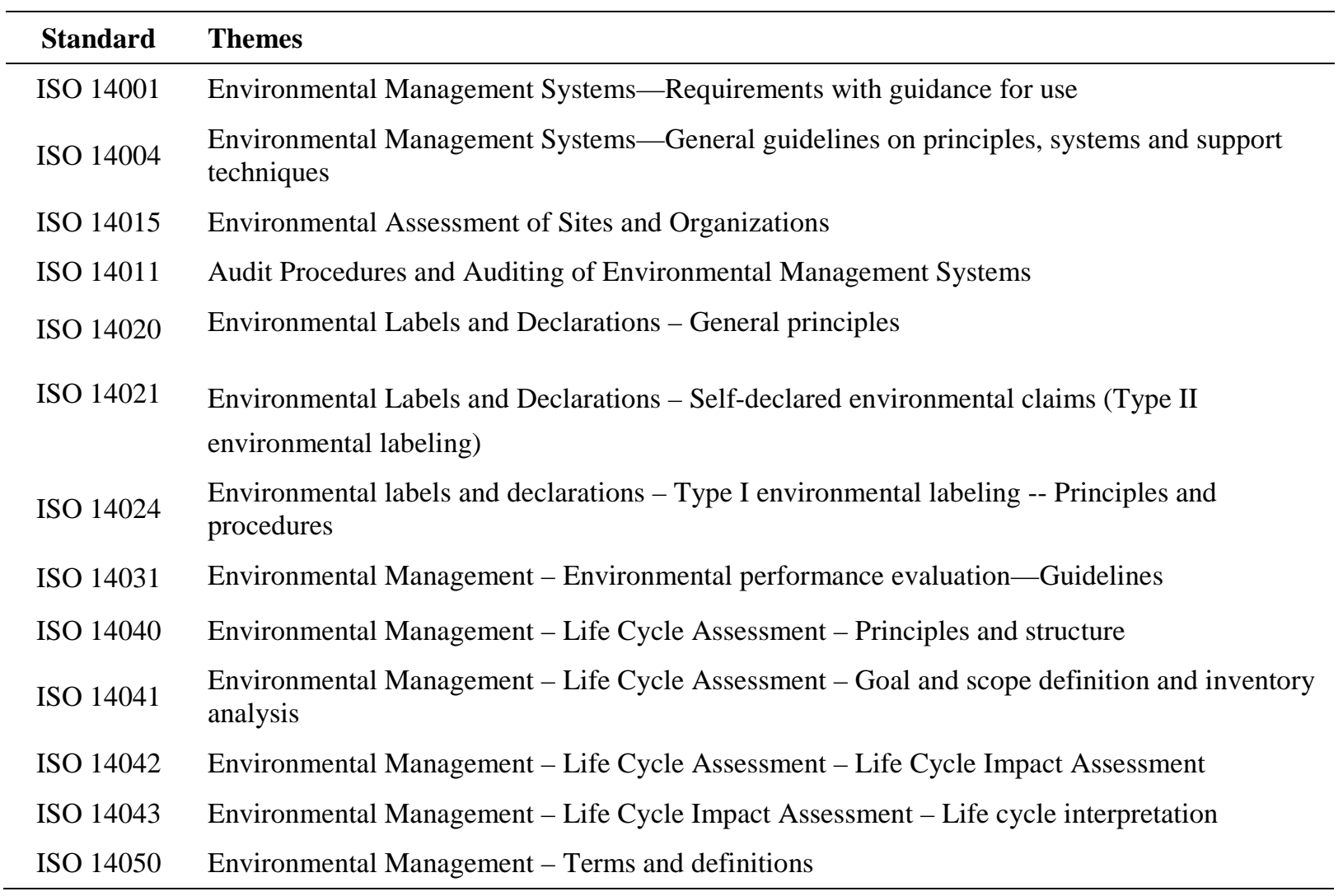

Note. Source: Associação Brasileira de Normas Técnicas. (n.d.). Relações empresas - ISO. Retrieved June 1, 2009, from http://www.abnt.org.br/m3.asp?cod_pagina=1006

The standards presented in Table 1 are part of the NBR ISO 14001 series, all of which are harmonious and independent, contributing in general to the certification process, irrespective of the firm's economic segment.

\section{Methodology}

\section{Methodological procedures}

Our goal was to identify the effect of certification of the environmental management system (EMS) by means of NBR ISO 14001:2004 on the financial performance of Brazilian firms with shares traded on the São Paulo Stock Exchange (BOVESPA), by calculating the average treatment effect (ATE).

To do this, we divided the sample into two groups, a treated group consisting of firms with environmental management systems certified by NBR ISO 14001:2004 and a control group made up 
of firms without this certification for their environmental management systems. Under this setup, the proxy for efficient environmental management is having NBR ISO 14001:2004 certification.

We analyzed this question by the difference in differences (DID) statistical model, to capture the effect of obtaining certification by comparing treated firms (i.e., those with certified environmental management systems) with untreated companies (control).

According to Meyer (1994), this statistical model requires controlling for the effect of the event (treatment) on other variables. This is done by attributing the number zero to the group before treatment or experiencing an event and the number one after treatment or experiencing the event (where the event is obtaining certification). Therefore, we assigned a value of one to Brazilian firms in the treatment group as of the moment they obtained NBR ISO 14001:2004 certification, and zero beforehand. We also assigned a value of zero to all the firms in the control group.

According to Coelho, Mello and Funchal (2011), when using the difference in differences approach, which compares the change in the results of the treated group before and after the intervention with the change in results of the control group over the same interval, the researcher manages to control unobserved factors that vary with time. Also, since we are using two side fixed effects we control for time-invariant heterogeneity (cross-section fixed effects) and for all common shocks (time fixed effects).

The DID model can be estimated with a linear regression model with dual fixed effects:

$$
y_{i t}=\alpha_{i}+\psi_{t}+\beta I S O_{i t}+\text { rcontr. }_{i t}+\varepsilon_{i t}
$$

where

. $y_{i t}=$ profitability.

. $\alpha_{i}=$ cross-section fixed effect.

. $\psi_{t}=$ time fixed effect.

- ISO = dummy ISOi; which takes on the value 0 for firms without NBR ISO 14001:2004 certification and 1 for firms with this certification.

- Ycontr.it $=$ control variable - total assets to control for size effects as gains of scale.

. $\varepsilon_{i t}=$ stochastic error.

If $\beta>0=$ DID coefficient $\rightarrow$ NBR ISO 14001:2004 has a positive effect on the dependent variable for treated firms.

If $\beta<0=$ DID coefficient $\rightarrow$ NBR ISO 14001:2004 has a negative effect on the dependent variable for treated firms.

To estimate the variable $y_{i t}$ (profitability), we considered net income and EBITDA as profitability measures. The use of these measures is justified by the following: the net income gives the amount of value created by the firm for shareholders, according to accrual based accounting; the EBITDA gives an approximation to the operational cash flow generated by the firm, according to cash based accounting ${ }^{(1)}$. We decided to use both measures as robustness check to the accounting regime: accrual vs. cash based accounting.

According to Lopes and Martins (2005), net income is perhaps the single most important number produced by accounting. It has numerous uses, such as measuring performance, allocating bonuses, valuing the firm and distributing dividends. 
In turn, according to Assaf (2002, p. 207), "the higher the EBITDA is, the more efficient the company is at generating cash flow from operations and consequently the better its capacity to pay debts, remunerate shareholders and make investments."

\section{Collection and selection of the data}

Our sample contains firm-specific accounting fiscal-year-end data on 552 publicly traded firms from 1996 (the year when NBR ISO 14001 was implemented in Brazil) to 2009 (the last period with published figures by the companies) ${ }^{(2)}$.

Currently, from the 552 firms with shares traded on the BOVESPA, 53 have NBR ISO 14001:2004 certification, according to information from the BOVESPA and the Brazilian Association of Technical Standards (Table 2).

Table 2

\section{Companies with NBR ISO 14001 Certification}

\begin{tabular}{|c|c|c|c|c|}
\hline & Company & $\begin{array}{l}\text { Year of } \\
\text { certification }\end{array}$ & Segment & $\begin{array}{l}\text { Accrediting } \\
\text { Body }\end{array}$ \\
\hline 1 & Aços Villares S/A & 2005 & Steel and Metallurgy & ABS \\
\hline 2 & AES ELPA S/A & 2005 & Electricity & $\mathrm{ABS}$ \\
\hline 3 & Aracruz Celulose S/A & 1999 & Pulp and Paper & BVQI \\
\hline 4 & Banco Bradesco & 2006 & Financial & $\begin{array}{l}\text { F.Carlos Alberto } \\
\text { Vanzolini }\end{array}$ \\
\hline 5 & Bardella S/A Indústrias Mecânicas & 2000 & Industrial Machinery & ABS \\
\hline 6 & Braskem S/A & 2004 & Chemicals & BVQI \\
\hline 7 & $\begin{array}{l}\text { Centrais Elétricas Brasileiras S/A - } \\
\text { ELETROBRAS }\end{array}$ & 1998 & Electricity & BVQI \\
\hline 8 & Companhia Bebidas das Américas - AMBEV & 1999 & Foods and Beverages & BVQI \\
\hline 9 & Companhia Energia de Minas Gerais - CEMIG & 2000 & Electricity & DNV \\
\hline 10 & Companhia de Energia de Pernambuco - CELPE & 2002 & Electricity & $\mathrm{ABNT}$ \\
\hline 11 & Companhia de Saneamento do Paraná - SANEPAR & 1999 & Others & ABS \\
\hline 12 & $\begin{array}{l}\text { Companhia de Transmissão de Energia Elétrica } \\
\text { Paulista - CTEEP }\end{array}$ & 2002 & Electricity & DQS \\
\hline 13 & Companhia HERING & 1997 & Textiles & DQS \\
\hline 14 & Companhia Iguaçu de café solúvel & 2002 & Foods and Beverages & SGS ICS \\
\hline 15 & $\begin{array}{l}\text { Companhia Paulista de Força e Luz - CPFL } \\
\text { Energia S/A }\end{array}$ & 2002 & Electricity & BVQI \\
\hline 16 & Companhia Siderúrgica Nacional & 2000 & Steel and Metallurgy & $\mathrm{ABS}$ \\
\hline 17 & Companhia Tecidos Santanense & 2001 & Textiles & DNV \\
\hline 18 & Companhia Vale do Rio Doce & 1997 & Mining & BVQI \\
\hline 19 & Dohler S/A & 1999 & Textiles & BRTUV \\
\hline 20 & DURATEX S/A & 1997 & Others & BVQI \\
\hline 21 & ELEKTRO Eletricidade e Serviços S/A & 2003 & Electricity & $\mathrm{ABS}$ \\
\hline
\end{tabular}


Table 2 (continued)

\begin{tabular}{|c|c|c|c|c|}
\hline & Company & $\begin{array}{c}\text { Year of } \\
\text { certification }\end{array}$ & Segment & $\begin{array}{l}\text { Accrediting } \\
\text { Body }\end{array}$ \\
\hline 22 & Eletropaulo Metropolitana EI - São Paulo S/A & 2000 & Electricity & $\mathrm{ABS}$ \\
\hline 23 & Embratel participações & 1999 & Telecommunications & FCAV \\
\hline 24 & Empresa Brasileira Aeronáutica S/A - Embraer & 2002 & Vehicles and Parts & $\mathrm{ABS}$ \\
\hline 25 & Eternit S/A & 2006 & $\begin{array}{l}\text { Non-metallic } \\
\text { Minerals }\end{array}$ & DNV \\
\hline 26 & Eucatex S/A Industria e Comercio & 2001 & Others & DNV \\
\hline 27 & Fosfértil & 2002 & Chemicals & $\mathrm{ABS}$ \\
\hline 28 & FRAS - LE S/A & 1999 & Vehicles and Parts & DNV \\
\hline 29 & GERDAU S/A & 2004 & Steel and Metallurgy & ABS \\
\hline 30 & Gradiente Eletronica S/A & 1999 & Electrical Appliances & BVQI \\
\hline 31 & Indústrias Arteb S.A & 2004 & Vehicles and Parts & ABS \\
\hline 32 & Itautec S.A - Grupo ITAUTEC & 2003 & Electrical Appliances & $\begin{array}{c}\text { F.Carlos Alberto } \\
\text { Vanzolini }\end{array}$ \\
\hline 33 & Karsten S/A & 2000 & Textiles & SGS ICS \\
\hline 34 & Klabin S/A & 1999 & Pulp and Paper & LRQA \\
\hline 35 & MAHLE - Metal Leve S/A & 2002 & Vehicles and Parts & DQS \\
\hline 36 & Marisol S/A & 2001 & Textiles & SGS ICS \\
\hline 37 & Mendes Júnior Trading e Engenharia S/A - MG & 2004 & Construction & BVQI \\
\hline 38 & Millennium Inorganic Chemicals Mineração Ltda & 2004 & Chemicals & BVQI \\
\hline 39 & Neonergia S/A & 2006 & Electricity & $\begin{array}{c}\text { F.Carlos Alberto } \\
\text { Vanzolini }\end{array}$ \\
\hline 40 & Perdigão S/A & 2003 & Foods and Beverages & BVQI \\
\hline 41 & Petrobras & 1998 & Oil and Gas & BVQI \\
\hline 42 & Positivo Informática S/A & 2000 & $\begin{array}{l}\text { Electrical and } \\
\text { Electronic Goods }\end{array}$ & BRTUV \\
\hline 43 & Sadia S/A & 1999 & Foods and Beverages & BVQI \\
\hline 44 & São Paulo Alpagartas S/A & 1997 & Textiles & FCAV \\
\hline 45 & Souza Cruz S/A & 2001 & Others & LRQA \\
\hline 46 & Suzano Papel e Celulose S/A & 2007 & Pulp and Paper & BVQI \\
\hline 47 & Suzano Petroqúímico S/A & 2004 & Petrochemicals & SGS ICS \\
\hline 48 & Telemig Celular s/A & 2004 & Telecommunications & BVQI \\
\hline 49 & Tupy S/A & 2001 & Vehicles and Parts & BVQI \\
\hline 50 & Usinas Siderúrgicas de Minas Gerais S/A - Usiminas & 1996 & Steel and Metallurgy & DNV \\
\hline 51 & Vicunha Textil S/A & 2001 & Textiles & BVQI \\
\hline 52 & Weg S/A 2001 & 2001 & Industrial Machines & BVQI \\
\hline 53 & Whirlpool S/A & 2006 & Electrical Appliances & BVQI \\
\hline
\end{tabular}

Note. Source: Associação Brasileira de Normas Técnicas. (n.d.). Relações empresas - ISO. Retrieved June 1, 2009, from http://www.abnt.org.br/m3.asp?cod_pagina=1006 
We excluded banks and insurers from the sample, because of the peculiarities of their business activities and the fact they publish financial statements following different rules than other firms, and also firms that decided to go dark or private. This exclusion reduced the total number of firms to 357, of which 52 have NBR ISO 14001:2004 certification.

Despite the number of firms in the treatment group and control group (with and without certification) being highly different (52 against 305 respectively) the number of observations is large enough to ensure the asymptotic properties of a panel (the Central Limit Theorem holds for the crosssection dimension).

\section{Results}

This section presents results regarding the effect of the ISO certification on firm profitability. We first present the results from the panel regression with fixed effects. Then, we move to the findings where we introduce the fixed effects on time dimension. All the regressions are robust to heteroskedasticity and serial correlation.

Table 3 presents the initial results of the tests carried out by panel regression with fixed effect. Panel A presents the impact of NBR ISO 14001:2004 on net income, and Panel B its effect on EBITDA.

Table 3

\section{Panel Regression with Fixed Effect}

Panel A: Panel Regression with Fixed Effect - Net Income

Dependent Variable: Net Income

Number of Observations: 3386

\begin{tabular}{lccc}
\hline & Coefficient & Standard Error & P-value \\
\hline NBR ISO 14001 & $37270.4^{* * *}$ & 135668.4 & 0.006 \\
Total assets & $.38738^{*}$ & .222004 & 0.081 \\
Constant & -47814.55 & 110345.5 & 0.665 \\
\hline
\end{tabular}

Note: Standard robust to heteroskedasticity and serial correlation.

* significant at $10 \%$; ** significant at $5 \%$; *** significant at $1 \%$

Panel B: Panel Regression with Fixed Effect - EBITDA

Dependent Variable: EBITDA

Number of Observations: 3182

\begin{tabular}{lccc}
\hline & Coefficient & Standard Error & P-value \\
\hline NBR ISSO 14001 & $965443.8^{* * * *}$ & 295012.6 & 0.001 \\
Total assets & 0.036 & 0.047 & 0.450 \\
Constant & 328914.2 & 252197.4 & 0.192 \\
\hline
\end{tabular}

Note. Standard robust to heteroskedasticity and serial correlation.

* significant at $10 \%$;* significant at $5 \%$; *** significant at $1 \%$ 
It can initially be seen that firms with NBR ISO 14001:2004 certification obtained an average increase of $\mathrm{R} \$ 372,720$ in net income, while their average EBITDA was $\mathrm{R} \$ 965,443$. Both values are significant at $1 \%$ level.

It is natural to ask if such effect could be driven by macroeconomic trends, such as economic growth for example, that increases firms' profits, or if it really is provided by the ISO certification. To capture the macroeconomic effect of firm profitability we introduced the time fixed effects, since it controls for all common shocks that vary over time. Thus, with the aim of capturing aggregated effects that could influence firms' bottom-line results, we used the regression with two-side fixed effects.

As can be seen in Table 4 - Panels A and B, the results obtained with the inclusion of the time fixed effects are still qualitatively the same and significant at $10 \%$ and $5 \%$ level, but the average impact declined. This is explained by the fact that part of the increase of the firms' profit previously estimated was coming from macroeconomic conditions, not only from the certification. However, notice that the economic impact of ISO certification is still relevant.

Table 4

\section{Panel Regression with Two-Side Fixed Effects}

Panel A: Panel Regression with two-side Fixed Effect - Net Income

Dependent Variable: Net Income

Number of Observations: 3386

\begin{tabular}{lccc}
\hline & Coefficient & $\begin{array}{c}\text { Standard } \\
\text { Error }\end{array}$ & P-value \\
\hline NBR ISO 14001 & $250128.9^{*}$ & 1322025 & 0.059 \\
Total assets & $0.038^{*}$ & 0.022 & 0.084 \\
Constant & -185131.8 & 131185.9 & 0.158 \\
\hline
\end{tabular}

Note. Standard robust to heteroskedasticity and serial correlation.

* significant at $10 \%$;** significant at $5 \%$; ** significant at $1 \%$

Panel B: Panel Regression with two-side Fixed Effect - EBITDA

Dependent Variable: EBITDA

Number of Observations: 3182

\begin{tabular}{lccc}
\hline & Coefficient & $\begin{array}{c}\text { Standard } \\
\text { Error }\end{array}$ & P-value \\
\hline NBR ISO 14001 & $646361^{* *}$ & 2883992 & 0.025 \\
Total assets & 0.034 & 0.047 & 0.466 \\
Constant & -34652.58 & 284672.2 & 0.903 \\
\hline
\end{tabular}

Note. Standard robust to heteroskedasticity and serial correlation.

* significant at $10 \%$;* significant at $5 \%$;** significant at $1 \%$

Controlling for the macroeconomic movements, firms with ISO certification obtained an average increase of about $\mathrm{R} \$ 250,000$ in the net income. Even though the p-value was 0.059 , the test can be considered significant at $10 \%$. Panel B demonstrates that the firms increased their EBITDA by an average of approximately R $\$ 646,000$ after obtaining NBR ISO 14001:2004 certification. Besides this, the result is significant, since the firms with NBR ISO 14001:2004 certification recorded higher EBITDA levels, with a p-value of 0.025 .

These results, presented in Tables 3 and 4, are in line with the theoretical literature of signaling and economic benefits of EMS, as stated by Akerlof (1970), Harrington and Knight (2001) and Rao 
and Holt (2005). Even though we cannot disentangle the effect of signaling from other benefits, both arguments go in the same direction. From signaling theory, the ISO certification serves to signal for the customers concern for the environment. It helps customers screen good firms from bad ones, increasing sales and profits for those deemed good. From the economic benefits perspective, the signal provided by the ISO certification allows firms to access funding sources (so-called sustainable financing) and international markets, which help to increase a firm's profits.

Our results are consistent with some findings from the empirical literature. Using return on assets as a dependent variable, Russo and Fouts (1997) and Jiangning (2006) found a positive relationship with environmental performance. Analyzing the steel markets, Rodrigues and Ferreira (2006) found a positive effect of ISO certification on firms' profits. On the other hand, Alberton (2003) found no statistical relationship between certification and abnormal returns; similar to results by Castro (2006), which used market value.

To get results of semi-elasticity, we ran the same models - panel with fixed effect and panel with two-side fixed effects - but used the dependent variable in a logarithm as presented at Tables 5 and 6.

Table 5

\section{Panel Regression with Fixed Effect - Logarithm}

Panel A: Panel Regression with Fixed Effect - Log: Net Income

Dependent Variable: Net Income

Number of Observations: 2151

\begin{tabular}{lccc}
\hline & Coefficient & $\begin{array}{c}\text { Standard } \\
\text { Error }\end{array}$ & P-value \\
\hline NBR ISO 14001 & $0.680^{* * *}$ & 0.107 & 0.000 \\
Total assets & $6.66 \mathrm{e}-09^{*}$ & $3.44 \mathrm{e}-09$ & 0.053 \\
Constant & $10.5609^{* * *}$ & 0.359 & 0.000 \\
\hline
\end{tabular}

Note. Standard robust to heteroskedasticity and serial correlation.

* significant at $10 \% ; * *$ significant at $5 \% ; * * *$ significant at $1 \%$

Panel B: Panel Regression with Fixed Effect - Log: EBITDA

Dependent Variable: EBITDA

Number of Observations: 2615

\begin{tabular}{|c|c|c|c|}
\hline & Coefficient & Standard Error & P-value \\
\hline NBR ISSO 14001 & $0.454 * * *$ & 0.057 & 0.000 \\
\hline Total assets & $2.02 \mathrm{e}-08^{* * *}$ & 2.91e-09 & 0.000 \\
\hline Constant & 11.40677 *** & 0.023 & 0.000 \\
\hline
\end{tabular}

Note. Standard robust to heteroskedasticity and serial correlation.

* significant at $10 \% ; * *$ significant at $5 \% ; * * *$ significant at $1 \%$

In Table 5, the result of Panel A shows an average increase in net income of $68 \%$, while that of Panel B shows an average increase in EBITDA of about 45\%, for firms with NBR ISO 14001:2004 certification, both significant at $1 \%$ level.

Again, to control for all common shocks that vary over time that may affect firm profitability, we tested the data again, using panel regression with two-side fixed effects. The results are shown in Table 6 - Panel A and Panel B and are aligned with previous results from Table 4. 
Table 6

\section{Panel Regression with Two-Side Fixed Effect- Logarithm}

Panel A: Panel Regression with two-side Fixed Effect - Log: Net Income

Dependent Variable: Net Income

Number of Observations: 2151

\begin{tabular}{lccc}
\hline & Coefficient & $\begin{array}{c}\text { Standard } \\
\text { Error }\end{array}$ & P-value \\
\hline NBR ISO 14001 & $0.246^{* *}$ & 0.120 & 0.041 \\
Total assets & 6.14 e -09 & 2.79 e -09 & 0.138 \\
Constant & $11.15931^{* * *}$ & 0.084 & 0.000 \\
\hline
\end{tabular}

Note: Standard robust to heteroskedasticity and serial correlation.

* significant at $10 \%$;** significant at $5 \%$; *** significant at $1 \%$

Panel B: Panel Regression with two-side Fixed Effect - Log: EBITDA

Dependent Variable: EBITDA

Number of Observations: 2615

\begin{tabular}{lccc}
\hline & Coefficient & $\begin{array}{c}\text { Standard } \\
\text { Error }\end{array}$ & P-value \\
\hline NBR ISSO 14001 & $0.113^{*}$ & 0.064 & 0.078 \\
Total assets & $1.65 \mathrm{e}-08^{* * *}$ & $2.70 \mathrm{e}-09$ & 0.000 \\
Constant & $11.89587^{* * *}$ & 0.056 & 0.000 \\
\hline
\end{tabular}

Note: Standard robust to heteroskedasticity and serial correlation.

* significant at $10 \%$; ** significant at $5 \%$; *** significant at $1 \%$

Even though the increases in both measures were not as great as before, since part of it was due to macroeconomic conditions, the average increase in net income stayed approximately at $25 \%$ and the EBITDA at 11\%: thus the NBR ISO 14001:2004 certification still boosted the values of these metrics. Both tests are statistically significant at $5 \%$ and $10 \%$ respectively.

In summary, all results point towards ISO certification having a positive effect on profitability measures. Controlling for all the heterogeneity between firms that is constant over time (cross-section fixed effects), for all common shocks that vary over time (time fixed effects), and for several unobserved factors that affect both groups, treatment and control, the increase brought by the ISO certification in net income and EBITDA is $11 \%$ and $25 \%$ approximately.

Based on agency theory, information asymmetry can be considered an important point in relation to the products and services offered by companies and their respect for the environment and consumers. One of the possible ways firms reduce information asymmetry is by the signaling mechanism, which in the case of environmental aspects can be done by establishing an environmental management system certified according to an international standard like NBR ISO 14001:2004. Firms that obtain this certification are signaling they are fully compliant not only with all Brazilian environmental legislation, but also with the enhanced international standards reflected in the certification.

By demonstrating this compliance, firms show they are doing their best to foresee possible negative environmental impacts of their activities. This strengthens their institutional image with stakeholders and reduces the risks of facing fines and penalties. 
The test results presented confirm the initial hypothesis that obtaining certification significantly increases firms' net income and EBITDA.

\section{Conclusion}

This study analyzed the relationship between the profitability of firms and obtaining certification of an environmental management system according to the NBR ISO 14001:2004 standard. To achieve this purpose, we investigated the behavior of two profitability indicators, net income and EBITDA, comparing certified companies against those without certification.

Based on the sample of Brazilian firms studied, using an experimental design called differencein-difference procedure to deal with endogeneity problems, our results show objective evidence that obtaining NBR ISO 14001:2004 certification improves profitability, as reflected by higher net income and EBITDA.

Our results show that on average, using the two-side fixed effects specification, firms that implemented the EMS certification get an EBITDA and a Net Income (our measures of profitability) $11 \%$ and $24,6 \%$ higher, respectively, than firms without EMS certification. Hence, this implies firms that implement EMS certification tend to increase their economic-financial results.

Our results coincide with findings from Russo and Fouts (1997) and Jiangning (2006) that use return on assets as a dependent variable, and showed a positive relation with environmental performance. Our results add to the literature analyzing the profit measures, which is the most important measure to shareholders.

Our result is explained mainly by the asymmetric information theory. The adverse selection problem can be considered as resulting from information asymmetry between parties, causing a reaction in the market as a whole, prompting firms to adopt signaling mechanisms. When firms obtain certification of their environmental management systems, they are sending signals and trying to reduce information asymmetry, thus increasing demand for their products and services.

A limitation of this study is that only Brazilian companies with shares traded on the BOVESPA were analyzed, due to the difficulty of obtaining financial data on unlisted companies.

Future works could expand on this article, by studying companies stratified according to various aspects, such as sector or whether their products and services are mainly aimed at the internal or external market, or both.

Received 14 December 2010; received in revised form 29 September 2011.

\section{Notes}

\footnotetext{
${ }^{1}$ See Mitton (2006), Skinner (1999) and Loughran and Ritter (2003).

${ }^{2}$ All data are from consolidated financial statements.
}

\section{References}

Akerlof, G. A. (1970). The market for "lemons": quality uncertainty and the market mechanism. The Quarterly Journal of Economics, 84(3), 488-500. doi: 10.2307/1879431 
Alberton, A. (2003). Meio ambiente e desempenho econômico - financeiro: impacto da ISO 14001 nas empresas brasileiras (Doctoral thesis). Universidade Federal de Santa Catarina, Florianópolis, SC, Brazil.

Ann, G. E., Zailani, S., \& Wahid, N. A. (2006). A study on the impact of environmental management system (EMS) certification towards firms' performance in Malaysia. Management of Environmental Quality, 17(1), 73-93. doi: 10.1108/14777830610639459

Assaf, A., Neto (2002). Estrutura e análise de balanço (7th ed.). São Paulo: Atlas.

Associação Brasileira de Normas Técnicas. (n.d.). Relações empresas - ISO. Retrieved June 1, 2009, from http://www.abnt.org.br/m3.asp?cod_pagina=1006

Bansal, P., \& Roth, K. (2000). Why companies go green: a model of ecological responsiveness. Academy of Management Journal, 43(4), 717-736. doi: 10.2307/1556363

Brazilian Association of Technical Standards. Retrieved June 1, 2009, from http://www.abnt.org.br

Castro, J. C. (2006). A influência dos sistemas de gestão ambiental baseados na ISO 14001 no valor de mercado das empresas brasileiras com ações negociadas na Bovespa (Master's dissertation). Universidade de Brasília, Brasília, DF, Brazil.

Coelho, C., Mello, J. M. de, \& Funchal, B. (2011). The Brazilian payroll lending experiment. Review of Economics and Statistics, 1, 1. doi: 10.1162/REST_a_00228

Gupta, S., \& Goldar, B. (2003). Do stock markets penalize environment-unfriendly behaviour? Evidence from India [Working Paper n 16]. Delhi School of Economics, Delhi, India.

Harrington, H. J., \& Knight, A. (2001). A implementação da ISO 14000: como atualizar o SGA com eficácia (F. G. Barroso \& J. G. de Araújo, Trans.). São Paulo: Atlas. (Original work published in 1999)

Henri, J. F., \& Giasson, A. (2006). Measuring environmental performance: a basic ingredient of environmental management. CMA Management, 80(5), 28-32.

Jensen, M., \& Meckling, W. (1976). Theory of the firm: managerial behavior, agency costs, and ownership structure. Journal of Financial Economics, 3(4), 305-360. doi: 10.1016/0304405X(76)90026-X

Jiangning, Z. (2006). The effect of the ISO-14001 environmental management system on corporate financial performance (Thesis graduate). School of Maharishi University of Management, Fairfield, Iowa, USA.

Klassen, R. D., \& Mclaughlin, C. P. (1996). The impact of environmental management on firm performance. Management Science, 42(8), 1199-1213. doi: 10.1287/mnsc.42.8.1199

Konar, S., \& Cohen, M. (1997). Information as regulation: the effect of community right to know laws on toxic emissions. Journal of Environmental Economics and Management, 32(1), 109-124. doi: 10.1006/jeem.1996.0955

Lopes, A. B., \& Martins, E. (2005). Teoria da contabilidade: uma nova abordagem. São Paulo: Atlas.

Meyer, B. D. (1994). Natural and quasi-experiments in economics [Working Paper $n^{\circ} 170$ ]. National Bureau of Economic Research, Cambridge, MA.

Nossa, V. (2002). Disclosure ambiental: uma análise do conteúdo dos relatórios ambientais de empresas do setor de papel e celulose em nível internacional (Doctoral thesis). Universidade de São Paulo, São Paulo, SP, Brazil. 
Rao, P., \& Holt, D. (2005). Do green supply chains lead to competitiveness and economic performance? International Journal of Operations \& Production Management, 25(9), 898-916. doi: 10.1108/01443570510613956

Rodrigues, A. C. M., \& Ferreira, R. N. do (2006). Gestão ambiental e rentabilidade de empresas siderúrgicas. Revista Brasileira de Contabilidade, (161), 47-63.

Russo, M. V., \& Fouts, P. A. (1997). A resource-based perspective on corporate environmental performance and profitability. Academy of Management Journal, 40(3), 534-559.

Sanches, C. S. (1996). A evolução da prática ambiental em empresas industriais: algumas considerações sobre o estado atual da arte e o caso brasileiro. São Paulo: FGV.

Schaltegger, S., \& Burritt, R. (2000). Contemporary environmental accounting: issues concepts and practice. Sheffield, UK: Greenleaf Publishing Limited.

Spence, M. (1973). Job market signaling. The Quarterly Journal of Economics, 87(3), 355-374. doi: $10.2307 / 1882010$

Tinoco, J. E. P., \& Kraemer, M. E. P. (2004). Contabilidade e gestão ambiental. São Paulo: Atlas.

Williamson, O. E. (1985). The economic institutions of capitalism: firms, markets, relational contracting. New York: Free Press.

Züst, R. (1997). Systems engineering - a methodology for life cycle engineering in interdisciplinary teams. Banbury, UK: ICED. 